\title{
Cesta k závislosti a zpět
}

\section{Martin Stanoev}

\begin{abstract}
Abstrakt: Článek přináší vybraná zjištění výzkumu drogových kariér zaměřeného na sociální konsekvence a představuje právě dokončovanou dizertační práci autora. Cílem výzkumu dizertační práce bylo zachycení proměn sociálního prostředí v případech individuálních drogových kariér těch jedinců, u nichž má proces závislosti počátek vadolescenci a již nepochází ze sociálně marginalizovaného prostredí. Dílčím cílem bylo odvození relevantních závěrů pro pomáhající profese. Vzorek tvoří osmnáct informantů, cílem konstrukce vzorku bylo zahrnout prípady srovnatelné povahy. Výzkum využívá designu a analytických postupů prípadové studie, hlavní a klíčovou metodu sběru dat představují hloubkové rozhovory se scénářem. Rozhovory měly prvky narativního interview a retrospektivně zjišt́ovaly drogovou kariéru. Vybraná zjištění se zaměřují na klima spojené s užíváním nealkoholových drog ve škole a třídním kolektivu, všímají si identifikace s antihrdinou závislého jako překvapivého motivu pro užití drog a analyzují moment bilance jako príležitost pro intervence pomáhajících profesí. Autor se snaží zasadit závěry do širších sociokulturních souvislostí a reflektuje dobový kontext utváření identity $v$ adolescenci a otázku normality/deviace ve vztahu k užívání nelegálních drog.
\end{abstract}

Kličcová slova: adolescence, deviace, drogová závislosti, prípadová studie, vrstevnické skupiny

\section{1 ÚVOD}

Tento článek přináší vybraná výzkumná zjištění dizertační práce autora. Na začátku práce byly položeny tyto otázky: jak Ize popsat proměnu sociálního prostředí u drogových kariér jedinců nepocházejících ze sociálně marginalizovaného prostředí? Co z těchto zjištění můžeme odvodit pro sociálně-pedagogické intervence? Design studie byl zvolen a aplikován v souladu s cílem zmapovat vybranou oblast sociálně-pedagogického výzkumu. Výzkum zachycuje aspekty spojené především s referenčními a vrstevnickými skupinami adolescence a sociálními skupinami závislých jedinců. Dále se zaměřuje na otázky dotýkající se role pomáhajících profesí. Výzkumu předcházela teoretická a konceptuální príprava zaměřená na problematiku adolescence a subkultur. Na aspekty subkulturního života spojeného s konzumací drog se tato stat' nezaměřuje. Tato stat' se zabývá predevším výsledky výzkumu zajímavými z hlediska sociální pedagogiky.

Zabývá se konzumací drog v kontextu třídního kolektivu. Všímá si motivu identifikace $s$ „antihrdinou závislého" pro užití drogy, který se objevil u některých informantů a autor ho považuje za překvapivý. Dále se zabývá motivací pro opuštění drogové dráhy a s tím již související otázkou role pomáhajících profesí a sociální pedagogiky $v$ terapeutickém a preventivním působení. Před seznámením s metodologií výzkumu stojí teoretický úvod. Ten představuje uvedení do kontextu výzkumu, kdy je nejprve analyzováno období adolescence jakožto období, ve kterém má drogová kariéra obvykle svůj počátek. Teoretický úvod si ještě všímá rozšířenosti drog mezi současnými adolescenty a je otevřena otázka normality/deviace ve vztahu ke konzumaci drog ve skupinách dospívajících. Tato teoretická témata měla své místo dále $v$ analýze dat a jejich reflexi. 
Stanoev / Cesta k závisloti a zpět

\section{TEORETICKÝ RÁMEC}

\subsection{Období adolescence}

Doba prvních experimentů s nealkoholovými drogami je obvykle spojena s obdobím adolescence. Pelikán $(2002,18)$ v odkazu na Eriksonovo pojetí vývojových etap považuje adolescenci ve výchově za určitý mezník. Zde se již vychovávaný stává více partnerem s předpoklady brát na sebe do určité míry zodpovědnost na jedné straně, na druhé straně právě nedostatečné uznávání dospělosti adolescenta je častou prričinou jeho vzdoru. Při bližším pohledu na charakteristiku tohoto období je zvýšená vulnerabilita dospívajících ve vztahu k návykovým látkám málo překvapivá. Macek (2003) rozděluje adolescenci na časnou:10(11) - 13 let, střední, situovanou mezi 14-16 rok a pozdní od 17 do 20 let, popř́padě i mnohem déle. Adolescence je období mezi dětstvím a dospělostí a pro ukončení adolescence nejsou tak důležitá biologická kritéria, jako kritéria psychologická (dosažení osobní autonomie), sociologická (role dospělého) a pedagogická (ukončení vzdělávací dráhy a získání kvalifikace). Je to období, ve kterém roste význam vrstevnických skupin jakožto specifického prostoru autonomie adolescentů.

Období adolescence může být nazíráno z různých perspektiv (Macek, 2003), pro tuto práci byla zvolena jako nejvhodnější perspektiva pro uchopení tématu pojetí adolescence jako období, které sebou nese specifické vývojové úkoly. Klíčových úkolem adolescence je dosažení autonomie a to jak v psychologické rovině, tak v rovině směřující $k$ dosažení ekonomické nezávislosti. Toto období, které je obdobím přechodu, nás má připravit na prijijetí zodpovědnosti a samostatnosti, dát nám schopnost obstát v rolích, které sebou nese dospělý věk. Psychologem, který analyzoval adolescenci z hlediska specifických vývojových úkolů, je psycholog $\mathrm{E}$. H. Erikson. Jeho práce byla ovlivněna psychoanalýzou, rozšiřuje však její pohled o psychosociální rovinu. S každým obdobím vývoje spojuje určitý konflikt, jehož překonání představuje vývojový úkol. $V$ adolescenci je oním vývojovým úkolem dosažení identity, ač toto představuje celoživotní proces, $v$ adolescenci se stává stěžejním konfliktem slovy autora: "identita versus zmatení identity", jinými slovy vadolescenci probíhá zápas o identitu (Erikson, 1999, 56).

Na Eriksonovo pojetí navázal Marcia (Marcia 1967; Macek 2003), který rozlišil čtyři potenciální stavy identity vadolescenci - ve výzkumu je operacionalizoval pomocí ideologie, náboženského přesvědčení a zaměstnání. Rozlišuje identity achievement - dosažení identity, foreclosure identity, doslovně by se dalo přeložit jako vyhoštěná identita, Macek překládá jako náhradní, uzavřená identita, dále identity difusion - rozptýlenou identitu a moratorium, tento výraz čeština zná, přeložit jej Ize jako odložení závazku. Pro určitá období adolescence jsou typičtější určitéstavy identity, nelze je však chápat striktně jako následná vývojová období. Dosažení identity (identity achievement) je ale třeba chápat jako konečné stádium adolescence. Potenciální rizikovost $\mathrm{s}$ sebou nese především období rozptýlené, difúzní identity. V pojetí Marcii ${ }^{1}(1967,551-553)$ v tomto období člověk nemá aktivní potřebu sebedefinování a je snadno ovlivněn svými vrstevníky, mění často své jednání v souladu s očekáváním skupiny. Jako rizikové lze hodnotit také období moratoria, kdy jedinec experimentuje smožnými rolemi, zažívá určitou krizi identity, která je doprovázena aktivním hledáním, bez přijímání hlubších závazků. Experimenty s drogou přestavují potenciální riziko pro zkoušení a hledání člověka, který nemá dostatek životních zkušeností.

Z tohoto úhlu pohledu se jeví drogová závislost započatá v tomto období jako závažné narušení ontogeneze psychiky. Namísto psychologické i životní autonomie a konstituování identity člověka přichází závislost na návykové látce. Ta, je-li rozvinuta, znemožňuje, nebo přinejmenším zásadně komplikuje naplnění vývojových úkolů tohoto životního cyklu. Vedle toho dva potenciální stavy identity v adolescenci - rozptýlená identita a moratorium (přijmeme-li Marciovu optiku), představují

1 Ač vychází Marcia z Eriksona, zde se s ním v užití tohoto pojmu rozchází. Není zde príliš prostor se touto otázkou zabývat, Erikson však tímto pojmem označoval spíše krizový stav identity v adolescenci. 
rizikové období pro zneužití návykových látek (i jiných nežádoucích jevů) svojí vnitřní logikou². Na druhou stranu proces zrání, který přirozeně probíhá, může být faktorem, který sehraje pozitivní roli, dle Nešpora je „tichým spojencem léčebných snah" (Nešpor, 2007, 52).

Pokusme se navázat na to, co bylo řečeno o adolescenci a zasadit problematiku dospívání do širších souvislostí. V Eriksonově teorii má důležitou úlohu koncept ideologie (chápáno bez negativních konotací). Adolescence potřebuje $v$ jeho pojetí ideologickou simplifikaci. $\vee$ textech tohoto autora se můžeme setkat s různými definicemi tohoto pojmu. Přijetí ideologie, která představuje něco mezi teorií a světonázorem, je důležité pro identifikaci jedince se širší společností, ve které žije ${ }^{3}$. Tradiční zdroje konstituování ideologie v Eriksonově pojetí jsou ekonomika, náboženství, politika, nacionální a regionální př́slušnost (Erikson, 1994, 31), na jiném místě Erikson zdroje konstituování ideologie rozšiřuje o vědu a umění (tamtéž, 257). Ideologie je definována Eriksonem jako systém idejí zabezpečující přesvědčivý obraz světa: „Používám toto slovo k popsání univerzální psychologické potřeby mít systém idejí, který zabezpečuje přesvědčivý obraz světa." (Tamtéž, 31)4.

Tímto pojetím se ale koncept ideologie nevyčerpává. Ideologie představuje pojítko mezi minulostí a budoucností. Spojuje vlastní dětství, jeho identifikace, které jsou ale již nefunkční, jeho hodnoty s historickou perspektivou, která sebou nese i perspektivu budoucího. Není tedy popřením minulého (hodnot osvojených ve společnosti, v rodině), ale spíše jeho aktualizací. Nalezení adekvátní ideologie je pro jedince důležité pro splnění vývojového úkolu - dosažení identity. Ideologie přijatá mladou generací má také význam přesahující jedince, má „očistný“ význam pro společnost. Mladá generace př́klonem $\mathrm{k}$ určité ideologii odhalí, co je $v$ hodnotách společnosti zastaralé a nefunkční anebo naopak živoucí a funkční i do budoucna. Z výše zmíněného je patrné, že s pojmem ideologie je zacházeno velice volně (o tvůrcích ideologie na jednom místě mluví Erikson jako o tvưrcích mýtů) a ideologie je chápána jako soubor idejí, které zakotvují jedince ve společnosti, ve světě 5 .

\subsection{Konzumace drog mezi dospívajícími v ČR a otázka normality/deviace konzumace drog}

ESPAD je mezinárodní projekt zaměřený na zjištování drogové prevalence mezi šestnáctiletými studenty a probíhá od roku 1995 každé čtyři roky. V České republice je realizován od samého počátku projektu a na jeho realizaci spolupracuje více institucí (Zaostřeno na drogy 1, 2012) ${ }^{6}$. V užívání nealkoholových drog mezi středoškoláky se od první studie ESPAD (1995) situace zásadně nezměnila. Vývoj celoživotní prevalence zjištěný u studie ESPAD 2011 byl u různých drog různý, ale oproti roku 2007 byl u většiny drog sestupný trend. Celoživotní prevalenci marihuany uvedlo 42,3\% respondentů, z nelegálních drog potom následují halucinogenní houby, které vyzkoušelo 6,9\% respondentů LSD 5,1\% a extáze $-3,3 \%$ respondentů. Pervitin uvedlo $2 \%$ respondentů, sedativa uvedlo $10,1 \%$ respondentů a těkavé látky 7,8 \% respondentů.

2 Volba výzkumného problému této práce souvisí s jedním dilematem - řečeno běžným jazykem, může se drogový problém týkat opravdu kohokoliv? Respektive, může se problém drogové závislosti týkat i jedinců, kteří kromě drog neinklinovali k jiným vážnějším výchovným problémům? A u kterých díky nezodpovědným volbám v době, kdy se učí svobodě, experimentování s drogami vyústilo v drogovou závislost, kdy cesta zpět k běžnému životu není jednoduchá.

3 Tato Eriksonova práce vznikala v 60. letech a je z textu patrné, že doba vzniku jej ovlivnila.

4 Přeloženo autorem studie.

5 Pro doplnění Eriksonovi koncepce dodejme, že zatímco ideologie, vyznačující se určitou simplifikací, je typická pro období adolescence, ve stáří se určitá témata hledání místa ve světě vrací, v této spojitosti však Erikson hovoří o moudrosti (1999).

6 Psychiatrické centrum Praha, Národní monitorovací středisko pro drogy a drogové závislosti, Lékařské informační centrum a agentura INRES-SONES. Z poslední studie ESPAD je zpráva, ze které autor čerpá, ke starším studiím jsou k dispozici detailnější výsledky (Csémy et al. 2009). Existují další studie, mapující toto téma (např. Falár̆, Bolek et al. 2003, 2004). 
Toto se týká celoživotní prevalence, v posledním roce užilo konopí 30 \% dotázaných a necelých $15 \%$ v posledních 30 ti dnech. Již 18,5\% respondentů mělo zkušenost s marihuanou do třinácti let věku. Pohlaví nemá velký vliv (dívky mají nižší prevalenci konopí a halucinogenních hub, naopak ale vyšší užívání sedativ), vliv má typ školy, kdy nejméně jsou drogy rozšířeny na gymnáziích a nejvíce na středních odborných učilištích. Ve vztahu k dostupnosti drog $59 \%$ respondentů uvádí, že by si dokázalo snadno obstarat marihuanu, $20 \%$ extázi a $9 \%$ pervitin. Užití konopné látky jednou nebo dvakrát v životě považuje za rizikové $22 \%$ respondentů, užití pervitinu $44,2 \%$ respondentů. $\mathrm{Na}$ základě výsledků autoři studie odhadují, že v populaci 15-19 letých adolescentů mělo zkušenost s užitím nelegální drogy okolo 250000 mladých lidí. Nicméně pozitivně lze hodnotit dle jejich soudu snižující se počet respondentů vykazujících zkušenost s nelegální drogou (konopím i jinými drogami) a to zejména u nekonopných.

Zkušenost s nealkoholovými drogami, zejména zkušenost $s$ marihuanou, nelze považovat $v$ kontextu dnešních adolescentů za něco výjimečného. Becker (1973) ve své zásadní práci o sociální deviaci Outsiders, study of the sociology of deviance, ilustroval právě na kuřácích marihuany (a jazzových muzikantech, přičemž zmiňuje, že jazzovým muzikantům není kouření marihuany cizí), svoji teorii deviace: teorii labellingu a sekvenční pojetí sociální deviace. Becker odmítá substanční pojetí deviace, které by chápalo některé jednání jako deviantní samo o sobě. Společnost konstituje pravidla, jejichž porušení představuje sociální deviaci. Deviantní jedinci však nejsou prostě ti, kteří pravidlo poruší, ale ti, na které pravidlo bylo úspěšně uplatněno. „Deviantní chování je chování, které tak lidé nálepkuji“ (tamtéž, 9)7. Otázka labellingu ve vztahu k užívání nealkoholových drog bude $v$ textu dále řešena. $V$ souvislosti s kouřením marihuany nicméně Becker uvádí: „Shrnuto, člověk se bude cítit svobodný kouřit marihuanu do té míry, do jaké bere ohledy na konvenční morálku neinformovaných lidí stojicích mimo, a do jaké míry nahradí jejich pohled "vnitřním“ pohledem, který si osvojil při zkušenosti s drogou ve společnosti dalších uživatelů." (Tamtéž, 78). Předkládaná data naznačují, že kontext kouření marihuany je dnes jiný a více světla do toho tématu vnese empirická část textu.

J. Young (1971) užívá ve vztahu k drogové problematice pojem "subterranean values" (doslova podzemní, tajné hodnoty). Ve společnosti dle Younga neexistuje hodnotový konsensus nejen mezi jednotlivými skupinami, ale inkonsistence existují i v rámci hodnot jedné skupiny (a takto existují rozpory i vindividuálním hodnotovém žebříčku). Vedle „oficiálních“ hodnot existují i ony „subterranean values" - patři mezi ně hledání potěšení, vzrušení. Jsou spojeny s volným časem a jejich podstata je hédonistická. Nejedná se o deviantní hodnoty - závisí však na tom, zda je vhodně zvolen kontext, ve kterém jsou použity, ${ }^{8}$ což např́iklad v prostředí velké části dnešních mladých lidí představuje páteční večer (noc). Některé skupiny ve společnosti však akcentují tyto hodnoty oproti hodnotám spojeným se světem práce - hodnotám produktivity, racionality a stř́́dmosti. A mezi tyto skupiny lze zařadit i některé subkultury mládeže.

Z tohoto pohledu Ize z hlediska norem, hodnot chápat určité vzorce chování, jednání jako odmítané, deviantní (spojené slabellingem, česky etiketou, „nálepkou“). Určité jednání je vhodné pouze $v$ určitých kontextech (jakožto neoficiální hodnota), např. během páteční noci a některé jednání je chápáno jako běžné, normální, je všeobecně akceptované a proklamované. Přijmeme-li postmoderní optiku plurality referenčních světů, musíme připustit, že různé skupiny se liší ve vnímání normality/deviace a jednou z distinktivních charakteristik je generační př́slušnost. Cestou ke zjištění vnímání těchto norem jsou dotazníková šetření. Pro zachycení klimatu ve vztahu k návykovým látkám Ize ale využít i kvalitativní metody a pojednávaný výzkum zachycuje z tohoto hlediska některé zajímavé aspekty. Před prezentací výsledků se krátce zastavme u metodologického postupu.

Přeloženo autorem studie, stejně jako následující citace.

8 Můžeme také říci, že spoustu členů společnosti sice oficiálně ( $v$ určitých kontextech) proklamuje určité hodnoty (také v sociologických šetřeních), v jiných kontextech je však poměrně cyničtější, nemusí se jednat jenom o návykové látky, ale napríklad také o sexualitu. 


\section{METODOLOGICKÝ POSTUP}

Cílem výzkumu dizertační práce bylo zachycení proměn sociálního prostředí $v$ př́padech individuálních drogových kariér těch jedinců, u nichž proces závislosti má počátek v adolescenci a kteří nepochází ze sociálně marginalizovaného prostředí. Dílčím cílem bylo odvození relevantních závěrů pro pomáhající profese.

\subsection{Organizace výzkumu a výzkumný vzorek}

Výběr vzorku, ke kterému se vztahují výzkumné závěry, byl záměrný: informanti museli splnit kritéria definovaná výzkumným problémem, tedy vznik drogové závislosti v adolescenci a nepocházet ze sociálně marginalizovaného prostředî ${ }^{9}$. Vzorek představuje osmnáct informantů, které zachycují dvě tabulky (viz niže).

Hlavní výzkum probíhal ve dvou terapeutických komunitách a je tvořen vzorkem 13 informantů. Informanti tedy byli lidé $v$ procesu léčby, předností čehož je rozvoj komunikačních schopností a reflexivního náhledu na situaci v průběhu léčby ${ }^{10}$. Před hlavním výzkumem probíhala prípravná fáze, kdy byl realizován rozhovor s pěti informanty. Cílem bylo zodpovězení některých předběžných otázek a príprava na komunikační situaci rozhovoru. Nicméně data dvou rozhovorů byla zahrnuta do výzkumu, nebot' obsahovaly pro analýzu plodné informace ${ }^{11}$. Třetí fáze probíhala za spolupráce s neziskovou organizací provozujícím doléčovací centrum, jejíz tři klienti byli ochotni sdělit svůj životní príběh. Data byla zahrnuta do výzkumu, cílem bylo upřesnit některé otázky a konfrontovat některé předpoklady $s$ dalším sběrem dat. Tyto rozhovory měly přispět ke zvýšení validity výzkumných závěrů.

Výzkum by nebyl realizovatelný bez ochoty spolupráce některých pracovníků organizací pomáhajících drogově závislým, především ale bez ochoty informantů sdělit otevřeně svůj životní př́běh. Všichni respondenti byli informováni o účelu výzkumu a zachováni důvěrnosti sdělených informací, pozměněním jmen osob a názvu míst v př́padě publikování výňatků z přepisů rozhovorů a souhlasili se sdělením svých životních príběhů a následně podepsali informovaný souhlas s účastí na výzkumu.

Informanti byli rodinným původem z dělnické, střední, případně vyšší střední vrstvy. Jsou zde zastoupeni informanti původem z Prahy, větších měst i menších sídel. Dominantní drogou byl pervitin, heroin, př́padně kombinace obou těchto drog. Vzorek zahrnuje šest žen a dvanáct mužů. Nikdo z informantů nedosáhl vysokoškolského vzdělání, některým se podařilo získat výuční list nebo maturitní vysvědčení, někteří nedokončili střední školu, kdy důvodem byla drogová závislost. Iniciační nealkoholovou drogou byla v šestnácti prípadech marihuana, v jednom prípadu extáze a $v$ jednom toluen. Většina informantů nebyla v léčebném procesu poprvé. Věk informantů se $v$ době rozhovoru pohyboval od dvaadvaceti do dvaatřiceti let. Do vzorku nebyli v rámci výzkumu v terapeutických zařízeních vybírání vedle jedinců ze sociálně-marginalizovaného prostředí ani jedinci z rodin, kde se objevovalo zneužívání a dále jedinci, kterým byla diagnostikována psychóza ${ }^{12}$.

9 K přiblížení chápání tohoto pojmu odkažme ke koncepci underclass nebo kultury bídy (Mareš, 1999, 179-184), v českém kontextu nejvíce charakterizujícím prostředí sociálně-vyloučených lokalit.

10 Rozhovor sjedincem aktuálně závislým na drogách ukázal na problematičnost využitelnosti takovéto výpovědi pro analýzu.

11 Jeden rozhovor nebyl nahráván, jeden probíhal s informantem, který nedokázal př́liš smysluplně sdělit svou zkušenost a úplně první rozhovor s informantkou byl spíše pouze přípravou na výzkumnou situaci - tyto tři rozhovory nebyly do analýzy zahrnuty.

12 Jeden rozhovor byl z analýzy pro nevěrohodnost vyřazen. 
Cílem selekce bylo vyloučit případy, jež by díky absenci základní příbuznosti nebyly porovnatelné. Následující dvě tabulky zachycují rok narození informantů a rok, kdy byl uskutečněn rozhovor:

Tabulka 1

Charakteristika vzorku I

\begin{tabular}{llllllllll}
\hline Jméno & Adéla & Bohouš & Cyril & David & Evžen & František & Gustav & Hana & Iva \\
\hline $\begin{array}{l}\text { Rok } \\
\text { narození }\end{array}$ & 1983 & 1983 & 1986 & 1979 & 1988 & 1983 & 1978 & 1979 & 1985 \\
$\begin{array}{l}\text { Rozhovor } \\
\text { roku }\end{array}$ & 2010 & 2010 & 2010 & 2010 & 2010 & 2010 & 2010 & 2010 & 2010 \\
\hline
\end{tabular}

Pozn. zdroj: autor.

Tabulka 2

Charakteristika vzorku II

\begin{tabular}{llllllllll}
\hline Jméno & Jaroslav & Karel & Leoš & Marta & Nela & Olga & Petr & Roman & Stanislav \\
\hline $\begin{array}{l}\text { Rok } \\
\text { narození }\end{array}$ & 1981 & 1981 & 1982 & 1988 & 1989 & 1982 & 1985 & 1986 & 1985 \\
$\begin{array}{l}\text { Rozhovor } \\
\text { roku }\end{array}$ & 2010 & 2010 & 2010 & 2010 & 2012 & 2012 & 2012 & 2009 & 2009 \\
\hline
\end{tabular}

Pozn. zdroj: autor.

\subsection{Design př́padové studie a analytický postup}

Zvoleným designem výzkumu byla osobní případová studie. Creswell př́padovou studii definuje následovně: „Kvalitativní přistup, ve kterém výzkumník zkoumá ohraničený systém (prípad) nebo více ohraničených systémů (prípadů) v čase skrze detailní a do hloubky mírící sběr dat zahrnující více zdrojů informací (např́klad pozorování, rozhovor, audiovisuální materiály, dokumenty a zprávy) a vytvárí popis prípadu a na prípadě založených témat." (Creswell, 2005, 73) ${ }^{13}$. V české metodologické literatuře je př́padová studie chápána jako svébytný př́stup (design) kvalitativního výzkumu (Švařiček, Šed'ová et al. 2007; Hendl, 2005). Tento výzkum zaměřený na jednotlivce a jejich drogové kariéry používá jako hlavní a klíčovou metodu sběru dat hloubkový rozhovor se scénářem ${ }^{14}$, $v$ př́padě třinácti informantů je tato metoda doplněna studiem kazuistické dokumentace a použitím story-line metody ${ }^{15}$ (dle Beijaard et al. 1999). Ve výzkumu byl důraz kladen na sociální konsekvence (proměnné, témata) drogových kariér a tím se odlišuje od biografického výzkumu, kdy je v centru životní príběh jednotlivce a jeho rekonstrukce. ${ }^{16}$

13 Přeloženo autorem studie.

14 Čas trvání jednoho rozhovoru se pohyboval kolem šedesáti minut. Rozhovor obsahoval seznam témat, zároveň se snažil témata spojit s volným prostorem k vyprávění životního příběhu. Při hlavní části výzkumu v terapeutických komunitách bylo určeno osm tematických okruhů: iniciační zkušenost s drogou, vrstevnické skupiny s rizikovým vztahem k drogám, zlom ve vztahu k drogám, škola, hudba a životní styl, vztah drog $\mathrm{k}$ identitě, ztráty spojené $s$ drogami, drogy a revolta. $V$ rozhovorech se spontánně vynořovala další témata. Tematický okruh škola byl spojen sotázkami postavení ve třídním kolektivu a pocitu sounáležitosti informanta ve vztahu $\mathrm{k}$ třídním kolektivu.

15 Studium kazuistické dokumentace a použití story-line metody proběhlo pouze v hlavní části výzkumu ve dvou terapeutických komunitách.

16 I když Ize říci, že zejména způsobem dotazování měl výzkum určité prvky biografického výzkumu a v některých aspektech se bližil realistické (pozitivistické) biografii. Z metodologické literatury byly čerpány podněty při analýze dat nejvíce z publikace Milese a Hubermana Qualitative data analysis (1994). 
Analýza postupovala od přepsaného textu ke kódům a od kódů ke kategoriím a od kategorií k tabulkovým znázorněním. Nejprve byl přepsaný text rozdělen na jednotky (sekvence) - obvykle se jednalo o odstavec nebo několik vět a ty byly označeny kódem. Často se jednalo o in vivo kódy (při kódování byla snaha vyjít z perspektivy informanta). Kódování bylo prováděno ručně, jednotka byla barevně označena a propiskou byl nahoru vepsán kód (tímto způsobem se autorovi s textem pracovalo nejlépe). Dále byly na základě soupisu kódů ( $v$ některých prípadech se analýza pochopitelně vracela $k$ přepsanému textu) vytvářeny kategorie. Kategorie představovaly určitá obecná témata, která se objevovala v jednotlivých kódech a zároveň měla analytickou relevanci. Pro přehlednost byly vytvářeny tabulky, které zachycovaly jednotlivé kategorie ve vztahu $k$ jednotlivým prípadům (dvě takovéto tabulky jsou v príloze). Potom byly $k$ jednotlivým případům zpracovány časové osy, které zachycovaly vybrané události a charakteristiky. Sledovaly logiku časového vývoje $\checkmark$ rámci jednotlivých prípadů. Pro analýzu byl charakteristický také iterativní postup, kdy se analýza vracela k přepisům rozhovorů a zvukovým nahrávkám, aby konceptuální představy konfrontovala s logikou jednotlivých př́padů.

\section{VÝZKUMNÁ ZJIŠTĚNÍ}

Výzkumná zjištění zde prezentovaná zachycují aspekty spojené sklimatem ve vztahu k nealkoholovým drogám v třídních kolektivech a školách, dále otázku motivů pro užívání drog. Vedle toho se zaměřuje na důvody rozhodnutí pro opuštění drogové dráhy a možnosti intervencí ze strany pomáhajících profesí.

\subsection{Konzumace drog v kontextu třídního kolektivu}

„....tak já jsem s těma klukama se šel někam podívat a ted'ka prostě najednou pro mě nové věci spousta lidí - a tak začaly ty akce. Úplně někde jinde, nové prostředí, noví lidi, najednou byli ti lidi úpIně fajn, protože byli zfetovaní, že. Takže mně se to prostě líbilo."

(Leoš:2010:1) $)^{17}$

Se světem adolescence je spojeno objevování. Pro Leoše a další informanty výzkumu byla s objevováním a zkoušením spojena drogová zkušenost. Na jejich experimenty a rozvoj závislosti není nutné se dívat jen perspektivou individuální trajektorie, ale je možné sledovat je v kontextu třídního kolektivu a jeho postavení v něm. Klima a normy tohoto prostředí lépe odrážejí obecné normy a klima ve vrstevnických skupinách společnosti, než je tomu u skupin přátel, které si volíme, nebot často vrstevníci volí jako své druhy vrstevníky s podobnými preferencemi. Je třeba zdůraznit, že vliv, jaký mají drogy pro postavení jedince ve třídním kolektivu, stejně jako norma ve třídě (či šířeji konkrétní škole) vztahující se k užívání drog, může nabývat různých podob. Pro tři informanty byla konzumace drog zdrojem "exkluzivity" ve třídním kolektivu a mezi vrstevníky obecně a propůjčovala jim určitý status, takto to bylo jimi alespoň subjektivně hodnoceno:

„....A postupně ta tráva najednou byl člověk někdo, jo. Lidi to mají tak blbě nastavené v hlavě, že prostě vzhližej k lidem, když kouřišs trávu."

(Evžen:2010:1)

„....Protože jsem vlastně uměl dělat tak akorát srandu a to bylo všechno. Nikdo mě nebral vážně, třeba když jsem potřeboval fakt něco vážnýho říct, takže tak, a pak jsem prostě začal chodit na hodiny češtiny, což češtinářka byla postrach. Tak na hodiny prostě zhulenej a kluci řikali ty vole, ty jsi frajer, já bych to nedal vís a takhle, takže to."

(Petr:2012:1)

17 Za jménem je označen rok rozhovoru a pořadí citací informanta v textu. 
„....jako jsem si pripadal jako někdo víc než oni. To zrovna fakt, jak ríkáš, vylítlo, bylo to nové a ted'ka já už jsem chodil na ty akce, oni ne a já jsem měl zkušenosti s těma drogama, oni ne a tak jsem si připadal možná jakoby ne nadřazený, ale prostě jakoby..., víc, no."

(Leoš:2010:2)

Leoš si také subjektivně připadal středem pozornosti školních kolektivů dvou středních škol, které studoval. Nicméně stejně jako dva další informanti, deklaruje v rozhovoru nízké sebevědomí $v$ době dospívání, pocity nejistoty (jeden z těchto informantů zmiňuje předchozí šikanu). Lze tedy toto subjektivní pojetí chápat jako svého druhu kompenzaci, je však zřejmé, že konzumace drog neznamenala rozhodně $v$ jejich případě odmítnutí vrstevníky a minimálně $v$ očích některých jim dodávaly tyto experimenty na atraktivitě.

Naproti tomu tři informantky z řad žen cítily naopak cizost ve vztahu ke tř́́dnímu kolektivu po přechodu na střední školu (u jedné z informantek se tento pocit cizosti objevil už na základní škole). $A$ byly také po nějaké době ze školy vyloučeny pro absence. $V$ tomto prípadě byla droga naopak zdrojem exkluze, což souviselo také $s$ tím, že $v$ době střední školy již dvě informantky užívaly vysoce rizikové drogy nitrožilně. Ilustrují to následující úryvky z rozhovorů vztahující se ke zkušenostem ze střední školy:

„No, tak určitě, treba na tý hotelovce se ti mí spolužáci, prostě oni věděli, že jsem nějaká jinačí nežli oni, protože jsem do školy moc nechodila a potkávali mě právě s divnejma lidima".

- -JO"

„A, takže se na mě dívali tak nějak divně, jo, takže mě mezi sebe vůbec nějak neprijjali." (Adéla:2010:1)

„....Já jsem byla úplně někde jinde, než oni. Tak tam nikdo z nich, dá se říct, jako někdo tam z nich kouril cigarety, jo, ale že by tam někdo bral drogy nebo to, to jako vưbec. A já, pro mě byly ty lidi úplně...já jsem si myslela, že jsem prostě jako úplně někdo jiný, než oni. Proto, já jsem si tam určitě s nikým vůbec nerozuměla, s nikým."

(Marta:2010:1)

„....S každým jsem se teda jako moc nebavila, ale na té střední škole, potom už, jak už jsem byla na těch tvrdých drogách, tak už jsem měla podmínečné vyloučení za šikanu teda."

$-J o$.

"No a do té školy jsem skoro vůbec nedocházela a jenom na praxi a... Pak mě vyhodili ze školy..."

(Iva:2010:1)

$\checkmark$ prípadech informantů mužů se u nikoho tak výrazný pocit odcizení a exkluze z třídního kolektivu neobjevoval, alespoň zpočátku. A stejně tak u zbývajících informantek. Jejich vnímání „sociálních zisků" a pocitů výlučnosti konzumace drog ale nebylo tak výrazné jako u prvních třech informantů.

Pokud však došlo k rozvoji drogové závislosti na střední škole, tak v určité fázi již k exkluzi z prostředí třídního kolektivu i běžných vrstevnických skupin dochází - toto dobře zachycuje životní osa informantů zachycená pomocí storyline metody (dle Beijaard et al. 1999). Jedinci zachycovali ve třech životních osách tři aspekty svého života na desetibodové škále v čase (pozitivní, negativní, neutrální hodnocení), jednou z těchto tři životních os bylo postavení jedince ve třídním kolektivu. Zde můžeme, na životních osách zachycují vývoj postavení v třídním kolektivu, identifikovat strmý pád hodnocení postavení ve třídním kolektivu spojený $s$ dobou počátků drogové závislosti, pokud k němu došlo na střední škole. Následná časová osa znázorňuje subjektivní hodnocení Leoše zachycující jeho postavení ve tř́dním kolektivu. Ač vyplývá (i z výňatků výše), že zpočátku vnímá své postavení velmi vysoko (i v souvislosti s drogovými experimenty), s rozvojem závislosti u něj dochází k strmému propadu. 


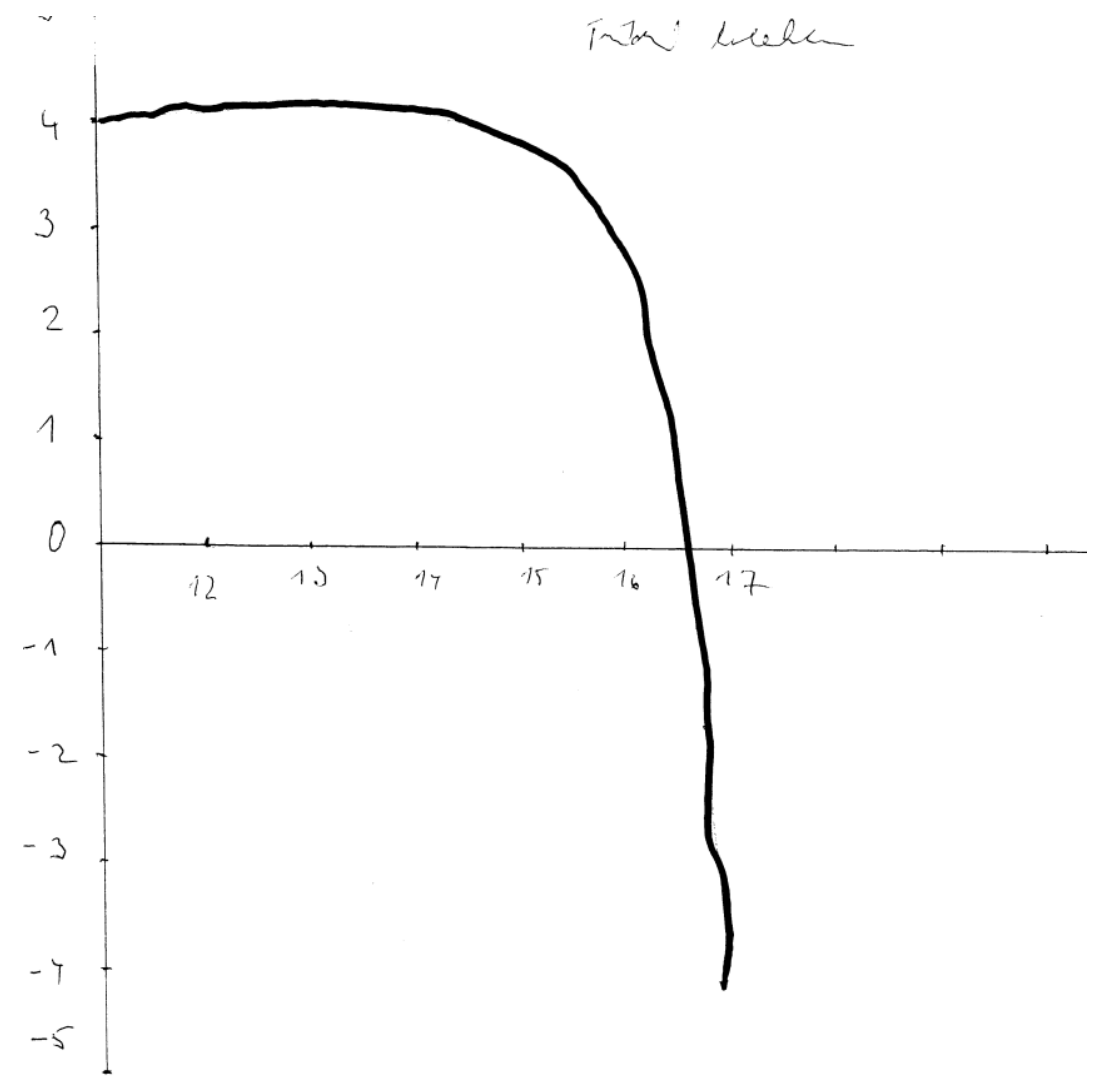

Obrázek 1. Životní osa Leoš: postavení ve třídním kolektivu.

Takovýto propad se však týká již počátků závislostí, ne experimentů, které takovéto dopady na sociální život dospívajícího obvykle nemají. Zajímavá je zkušenost s reakcemi vrstevníků, kterou popisuje Jaroslav a vztahuje se k rozdílnosti dvou referenčních světů, se kterými se setkal:

„T: Vy jste byli prostě těch lidí co...

J: Kouřili tu trávu...

M: Takže to byla spíš jako taková, mimo jiné i společenská záležitost.

J: Společenská záležitost, jasně. Protože jsem se tlačil do té společnosti, kde to bylo jo

M: Jo

J: Jo, netlačil jsem se do té společnosti, kde to nebylo, společnost, která tyhle věci nedělá, nebo tohle, tak tady tyhle lidi vytlačuje. Jo to bych se asi necítil dobře, protože já jsem v tu dobu chtěl kouřit, prostě, chtěl jsem zkoušet prostě tady tyhle věci, chtěl jsem experimentovat, no a tím pádem jsem zapadl do tady téhle společnosti."

T: „A třeba nějakou nálepku jako fetáka, to jsi ale neměl...?“

$\mathrm{J}:$ „to ne, to ne, to až později před tou vojnou, to spíš, nálepku jako fetáka, když to tak řeknu, v těch svých sedmnácti, osmnácti letech, než jsem ukončil vlastně střední to učiliště".

T: „No a to bylo z toho důvodu, že už jako bylo poznat...?"

J: „No že už na mě prostě bylo vidět ten styl prostě, jo, toho oblíkání, prostě už tam byl jako dá se říct extrémní, jo, dlouhé mikiny až po kolena, prostě, ty kapuce, jo, člověk chodil se zarudlýma očima, když to tak řeknu..." 
(Jaroslav:2010:1)

Z citace vyplývá, že Jaroslav se necítil outsiderem v pravém slova smyslu. Tím se stal, až když konzumace drog měla podstatné a viditelné negativní dopady na jeho život (z rozhovoru vyplývá, že $v$ té době již užíval širší škálu drog). O skupině kuřáků marihuany v tomto kontextu nelze hovořit jako o outsiderech v pravém slova smyslu. Spíše Ize chápat svět kuřáků marihuany jako alternativní ke světu vrstevníků, kteří s drogami neexperimentují. A jak je ukázáno dále, majoritou v trídním kolektivu mohou být i kuráci marihuany.

Normy ve třídě (či obecněji škole) vztahující se ke konzumaci drog vykazovaly určitou variabilitu. Tyto normy byly s tím, jakou roli mají drogy pro postavení jedince ve třídě, úzce spjaty. Mohli jsme se setkat $s$ třemi modalitami této kategorie - $v$ určitých třídních kolektivech byla konzumace drog výjimkou, potom se mohl respondent vnímat jako černá ovce, či dokonce být vyloučen z kolektivu, jak k tomu odkazují uvedené výňatky z rozhovorů Marty, Adély a Ivy, ale vztah vrstevníků k jeho experimentům i $v$ této situaci mohl být relativně neutrální. Tato modalita byla $v$ prezentovaném výzkumu nejčastější. Druhou modalitou jsou ony dva světy, kdy na školách byly do určité míry separované skupiny experimentujících (méně početná skupina) a těch $\mathrm{s}$ odmítavým postojem $\mathrm{k}$ drogám. Existovaly však také třídní kolektivy, kde bylo konzumování drog velmi rozšířeno a dá se říci, že se stalo normou, prípady této třetí modality se $v$ tomto výzkumu objevily $u$ tří třídních kolektivů a jednalo se o učební obory (týkaly se však jen dvou informantů). Cyril popisuje marihuanu jako určité pojítko třídního kolektivu.

„....A hodně jsem si rozuměl s těma lidma, protože ta naše třída byla dost propojená tím, že jsme skoro všichni kouřili marihuanu, takže jsme měli společný zájem, takže jako většina třídy takhle kouřila tu marihuanu."

(Cyril:2010:1)

Tabulka 3. v príloze zachycuje kategorie drogy ve vztahu k třídnímu kolektivu a sociální důsledky konzumace drog v třídním kolektivu pro jednotlivé př́pady (informanty).

\subsection{Drogově závislý jako antihrdina}

Otázka motivů je přirozeně jedna z prvních otázek, které bývají kladeny v prípadě drogových experimentů. Ve vztahu k obvyklému chápání tohoto tématu přináší jedno překvapivé zjištění. Motivy Ize hledat u některých informantů v získávání sociálního statusu (viz výňatky z rozhovorů výše) a u všech z nich v příslušnosti v referenční skupině akceptující a podporující drogy. Ta je obvykle spojená s obecnější scénou, at' už se jedná o některou z tanečních scén, subkulturou spjatou s kouřením marihuany nebo graffiti, hip hop a punk. Na konzumaci drog můžeme nahlížet jako na jev rezonující s určitými přirozenými tématy adolescence, kterými jsou vedle zkoušení, experimentování, hledání identity, odlišnosti, vlastní hodnoty. Nicméně překvapivým zjištěním spadajícím do oblasti motivace byl zájem o drogy a osoby drogy užívající drogy, předcházející prvnímu užití drogy. Drogově závislý, „feták", sehrál roli antihrdiny, se kterým se dospívající identifikuje. Drogy takto mohly být chápány jako cesta $\mathrm{k}$ nalezení svobody a symbol bohémského života. Tuto fascinaci bohémským životem a svobodou popisuje Adéla a právě drogy pro ni byly jejím ztělesněním.

„Všechny, takový knižky kde se, kde byly popsány, jako ty stavy na těch drogách jo. Co která droga s tím organismem jakoby dělá. Já přesně nevím, jak se jako jmenovaly, ale takový ty klasický, jako My děti ze stanice Zoo a různý jakoby i príběhy těch lidi".

A: „Jakože mě úplně děsila nějaká průměrnost. Chodit do práce a žít jako..."

T: „Dívat se na televizi..." 
A: „Dívat se na televizi, to mě vždycky fascinovalo takovej ten bohemskej život, no. Prostě nedodržovat žádný pravidla a ... a prostě si dělat co chci jako. Abych se nemusela nikomu zodpovídat, ani rodině, ani, ani... Prostě ta svoboda absolutní mě hrozně přitahovala."

(Adéla:2010:2)

"Sémantika" pojmu droga byla v tomto případě spojena až s určitým „drogovým romantismem“, předchozí fascinace drogami byla patrná i v př́ípadě Evžena:

„...Mně už to zajímalo dřiv, díval jsem se na nějaké dokumenty, četl jsem Memento, že jo. Já jsem se o to zajímal prostě, mě to nějak k tomu táhlo k těm drogám. No a najednou byla možnost si to vyzkoušet, že jo. Tak jsem to zkusil a zalíbilo se mi to."

(Evžen:2010:2)

Tuto silnou fascinaci světem drog předcházející závislosti i experimentům s drogami bylo možné identifikovat u sedmi informantů ( $v$ jednom dalším případě byla silná přitažlivost a fascinace drogami založena spíše na sociálním základě). Nabízí se otázka - odkud se představa závislého jako romantického antihrdiny bere a zajímavé je, že $v$ těchto prípadech prevence často sehrávala opačnou, nežli zamýšlenou, roli.

„Tady to a já jsem vlastně i ze škol. Vlastně to mě taky. Tam jsme vlastně měli různé, chodili z Káčka k nám do školy, dělali přednášky, my jsme chodili k nim, o těch drogách, a nebo AIDS a tak. A to mě prosto taky, to mě fascinovalo, já jsem to měla hrozně ráda. Mě to bavilo a vlastně je fakt, že to byl návod k drogám taky... A vlastně jsme se na to i koukali v televizi. Pamatuji si, že jsme koukali na různé príběhy nějakých těch lidí., kde vlastně taky jsem viděla přesně, jak to jako chodí venku a mě to strašně nějak fascinovalo. Já nevím proč..."

(Marta:2010:2)

Nepřekvapí, že roli modelu zde můžou sehrát také rockové hvězdy:

„jo, mně se to líbilo, jakože to je prostě takový nekonformní a nelíbilo se mi to, nelíbili se mi ty normální lidi prostě. Já jsem si myslela, že mezi těma lidma a mezi těma, co berou drogy, že je něco jiného. Mně se nelíbily tady ty vztahy a tak a líbilo se mi, jak jsem se ztotožňovala s tím Cobainem jako, jak úplně řval a ječel, tak úplně jsem se cítila jako. Takže to bylo jako moje hudba a můj styl jakože."

(Olga:2012:1)

Poukažme na skutečnost, že konzumace drog, kterou lze chápat jako určitou formu hédonismu, $v$ těchto prípadech naznačuje určitou ambivalenci. Není jen hledáním nevšedního štěstí, postavy, které sehrávají roli modelů, antihrdinů, zároveň často trpí, jsou vyděděnci a lze snad předpokládat i jejich zvýšenou citlivost ${ }^{18}$. Identifikace s nimi bude mít nepochybně hlubší kořeny (než např. jen snahu revoltovat, provokovat), vyžadující spiše psychologickou analýzu. Zda se objevovala fascinace drogami od dětství a další naznačené motivy u jednotlivých případů (informantů), zachycuje tabulka 4. $v$ príloze.

\subsection{Bilance jako př́ležitost ke změně a role pomocníků}

Určitým obecným tématem „vyprávěni“" „narace“ informantů byl prvek bilance. Lze ho předpokládat $u$ všech informantů, pouze v některých výpovědích nebyl explicitně výrazně pojmenován (to je prípad pěti informantů). Bilance se objevují v různých fázích drogové cesty. Poprvé v době určitého odcizení běžným vrstevníkům a ve chvilích, kdy je patrný již určitý vliv drogových zkušeností na život

18 Tu můžeme vysledovat v literárních ztvárněních, jak je např. zmiňovaná kniha My děti ze stanice ZOO, nebo i v některých př́bězích rockových hvězd. 
- např. v podobě určité ztráty fyzické kondice. Je to také určitá reakce na silnější odcizování běžným vrstevnickým skupinám. To zachycuje citace z rozhovoru Gustava a Cyrila:

„Na, já jsem měl takový talent. $V$ tu dobu jsem jakoby nesportoval aktivně. Jsem zrovna ten bikros jako nedělal...v tu dobu jsem nesportoval aktivně, a tak nějak šlo o více věcí najednou - ve škole se mi nedařilo, doma mi nadávali, brácha byl neštasný, ted' ten kámoš z ulice, ten byl jako o něco starší... který je ted' učitel, on vždycky kouřil jenom trávu a věděl, že tohle už je jakoby špatně. A tak mi jako...Já jsem za ním někdy chodil s brekem, že je mi to líto, jak vypadám a už mi jakoby i lidi hodně ř́kali, že jako hubnu a že jsem zle doštípaný, někteří lidi na mě koukali preses prsty z ulice, a tak jako více těch aspektů..." ${ }^{19}$

(Gustav:2010:1)

„To mi bylo šestnáct, když jsem si řekl, že... vlastně jsem seděl v jedné hospodě a byl jsem zfetovaný a ř́kám, vždyt' já vlastně jsem úplně v prdeli, já vlastně už asi... já rok fetuju... já prostě na těch drogách ujiždím. Měl jsem, já nevím, šedesát pět kilo a už fetáci mi řikali, že vypadám blbě, tak at' s tím něco dělám. No a takhle... Jako nebral jsem to nějak za důležité, tak jsem v tom prostě pokračoval dál, až do sedmnácti let, kdy já vlastně..."

(Cyril:2010:2)

Toto je první moment bilance, se kterou se můžeme setkat $v$ období počátků závislosti, objevuje se nejenom v souvislosti s reakcemi okolí, ale také např. v souvislosti s tzv. dojezdy (tedy po odeznění intoxikace pervitinem). Ještě silněji se však bilance objevuje v situaci pádu na dno. Může mít podobu konfrontace s „normálním životem“. Setkání s páry milenců, které se drží za ruce a vyzařuje z nich spokojenost. Toto Ize interpretovat jako vliv projekce určité vlastní představy o budoucnosti osvojené $v$ dětství, se kterou byli informanti konfrontováni. Pokusíme-li se toto téma konceptualizovat v souladu s Bergerovou a Luckmanovou $(1999,128-144)$ teorií socializace - prí primární socializaci v rodině si člověk osvojí určité vzory, modely, zároveň určité představy o tom, jaký by život měl být $v$ pozdější fázi. $U$ informantů výzkumu pokračovala socializace $v$ adolescenci socializací do subkultury drogově závislých. Tedy po primární socializaci, kdy se včleňujeme do určitého segmentu společnosti, se informanti začlenili od subkultury, kterou můžeme označit jako deviantní. Použijeme-li terminologii zmiňovaných sociologů, nejednalo se o sekundární socializaci (která více či méně plynule navazuje na socializaci primární), ale alternaci. A jakoby v momentu bilance se ozvala neadekvátnost tohoto osvojeného světa z hlediska primárních, původních osvojených představ o životě a jeho průběhu (můžeme použít př́iměr „prekurzoru“). A alternace, tedy socializace nahrazující původní osvojenou představu světa a hodnot, jeho totální transformace, nenabízí v tomto prípadě dostatek pozitivních záchytných bodů. ${ }^{20}$

A pak je tu samozřejmě negativní rozměr - informanti jsou v tento moment často bez střechy nad hlavou, zažívají negativní příznaky po odeznění účinků pervitinu, jsou ve zbídačeném stavu a jsou v tuto chvíli konfrontováni s „obyčejným štěstím“, jak to zachytili ve svých výpovědích Leoš a Evžen.

„No (smích), my jsme seděli, teda já jsem stál, protože kluci byli pryč někde a já jsem stál na Václaváku a koukal jsem, to už jsem jako hodně měl za sebou a koukal jsem na ty lidi, jak tam chodí, na ty rodinky s dětma v tom kočárku a řekl jsem si, že takhle nechci žít. Že chci mít taky tu rodinu. A tak se mi zastesklo po mámě, a vlastně jsem šel do toho M..."

(Leoš:2010:3)

"To bylo před... Když jsem se vlastně poprvé dostal na tu ulici, no. Když už to rodiče nezvládli, já jsem věděl, že sám dokázat brát neprestanu. To bude takové dva, skoro no, něco přes dva a půl roku.

19 Zde se objevuje také téma stigmatizace a $v$ přechozí kapitole téma zmíněné odcizování běžným vrstevnickým skupinám, pokud konzumování drog přeroste určitou míru.

20 Prototypem alternace je podle zmiňovaných sociologů náboženská konverze, která obvykle nabízí více nosných aspektů identitě. 
Skoro ty tři roky zpátky asi. V létě a to už jsem věděl, že to je zlé, no. Prostě styděl jsem se za sebe jak vypadám a tohle. Když člověk prostě viděl nějakou pěknou holku, jak si vykračuje někde s klukem, tak jsem se podíval na sebe a ríkal jsem si ty vole, to není dobré."

\section{(Evžen:2010:3)}

Evžen popisuje zkušenost před Vánocemi, po které se vrátil k rodičům. Po nějaké době se opět uchýlil k drogám. Leoš popisuje zkušenost, po které následovalo rozhodnutí pro léčbu. I u výpovědí jiných informantů jsou často moment bilance a rozhodnutí pro léčbu spojeny. Mohli bychom vytvořit určitou kostru príběhu: fascinace drogou předcházející iniciační zkušenosti - oslovení drogou a následné propadnutí - volání domů a cesta zpět. Tato kostra je explicitně obsažena jen v některých výpovědích (zejména v případě prvního bodu je jednoznačné, že se netýká všech informantů).

Nicméně jsou to zážitky a představy osvojené v primární socializaci, které volají člověka zpět, „,domü“ (použijme metaforou „prekurzoru“). Jedinec sám pouze s pomocí rodičů však obvykle selže, alespoň vycházíme-li ze zkušenosti informantů výzkumu. Výzkum byl zaměřen i na hodnocení zkušeností s pracovníky pomáhajících profesí. Část informantů byla knávštěvě pomáhajícího pracovníka přinucena $v$ době, kdy jejich experimentování (nebo to mohlo být již v době počátků závislosti) objevili rodiče. Všichni s touto zkušeností se shodnou, že prínos těchto intervencí nebyl žádný. Shodnou-li se na něčem takřka všichni informanti, pak je to ocenění terapeutů jako naslouchajících, nehodnotících, komunikujících pracovníků nabízejících pomocnou ruku. Někteří jsou v tomto hodnocení zdrženlivější, někteří naopak roli terapeutů staví velmi vysoko. Je to prípad Hany, která terapeutům přičítá obnovení důvěry $\mathrm{k}$ dalším lidem a také Olgy, která vyzdvihuje práci jednoho konkrétního terapeuta:

„....Prostě mě ty drogy, já jsem na těch drogách pomalu přestávala věřit, nikomu jsem nevěřila, prostě jenom já jsem věřla sobě. Začala jsem díky nim zase důvěřovat lidem (pozn. myšleno díky terapeutům), jo. Že prostě, že když někdo něco řekne, tak mu věřím. Prostě, dřív jsem...Tohle. Pak jako mi pomohlo najít cestu k lidem normálně. Jo, že já jsem prostě nedokázala se bavit."

(Hana:2010:1)

„no mě, já jsem se jako s ním naučila strašně moc věcí. Já prostě, když si ho takhle vybavím jo, když si vybavím prostě L... M..., tak prostě já ho mám spojenýho s tím, že prostě všechno má řešení jako. At' jsem byla v jakékoli situaci, jo že potom jsem prostě přestala abstinovat a zase jsem sešupla úplně dolů, tak já jsem s ním, on člověka dokáže, já jsem debil (slzy). Jakože vždycky si prostě sedneme a on rekne Olgo...".

(Olga:2012:2).

Z výpovědi je zřejmé, že vedle prostoru pro komunikaci informantka oceňuje také otevírání určitých řešení, alternativ. Tato stránka nebyla ve všech výpovědích obsažena, někteří informanti zůstávají u vnímání terapeuta jako naslouchajícího, sdílejícího. Je možno říci, že všichni informanti akceptují platformu léčby. Někteří informanti vyzdvihují také prvek svépomoci v léčbě, jak se odehrává $v$ terapeutické komunitě. Celkově zde rezonuje př́stup orientovaný na klienta. ${ }^{21}$ Následující citace z rozhovorů Petra a Nely se vztahují k tématu prínosu komunitní léčby a zachycují Petrův postoj $\mathrm{k}$ možnosti pomoci terapeutů.

$T:$ trreba podle toho čím můžou získat tu vaši důvěru, nebo i to, že jste ochoten o těch věcech mluvit...

$P:$ :já jsem nějak v první radě nasloucháním, nějaký jako, že v tom jsou se mnou nebo tak nějak, když to, když to tak nějak vycítím, když třeba mám něco těžkýho, tak prostě vím třeba, že mi nemůžou pomoct, ale můžou vtom se mnou jenom bejt jako."

21 Pro přiblížení lze odkázat na C. Rogerse a jeho tři předpoklady: autentičnosti, opravdovosti, kongruentnosti terapeuta, dále terapeutovu akceptaci klienta, jeho bezpodmínečné pozitivní přijetí a posledním předpokladem je empatické porozumění (Rogers, 1998, 106-107). 
(Petr:2012:2)

„....Zjistil jsem, protože ta komunita mně dala opravdu to, co jsem nějak chtěl, ale neměl jsem to pojmenovaný a to bylo prostě jenom zázemí22..."

(Petr:2012:3)

„komunita, ono to bude znít asi, jak bych to řekla, asi divně, ale komunita mi dala za ten rok, co jsem tam byla, za těch 13 měsíců víc, než za celý život moje rodina a to myslím vážně, jo." (Nela:2012:1)

\subsubsection{Role sociální pedagogiky}

Na základě výpovědí informantů Ize soudit, že určitou roli může sehrát nespecifická prevence, v podobě nízkoprahových klubů pro dospívající, streetworkerů, která je postavena na podobných filosofických principech jako terapie a pomoc závislým, tedy na nehodnotícím, partnerském přistupu. Zde se otevírá prostor pro sociální pedagogy jako průvodce dospívajících. Pokud si sociálního pedagoga dospívající nespojuje se světem autorit, vưči kterým může pocitovat nepřátelství nebo znatelný odstup, může jej v určitých situacích vyhledat a požádat o pomoc či radu.

Z dat vyplývá, že dospívající v době pokročilých experimentů a počátků závislosti zažívá též určité krize, bilance (viz citace z rozhovoru Gustava a Cyrila) a v nich mu může sociální pedagog pomoci v nacházení nových perspektiv. $\vee$ nich může vznikat také určitá poptávka po pomoci a tím se otevírá naděje pro terapeutické působení, či alespoň určitou průvodcovskou roli sociálního pedagoga jakožto neformální autority (srov. Pelikán, 1992).

Zajímavé je zmínit, že část informantů měla v době dospívání poměrně bohaté sportovní zájmy, to uvádí osm informantů ( $z$ toho jenom jedna žena). Přesto u nich zvítězil životní styl spojený s konzumací drog a sportovní záliby opustili. Tezi „sportem proti drogám“, Ize dle soudu autora vytknout určitou naivitu. Pro dospívajícího jedince ve střední a pozdní adolescenci obvykle nenabízí sport jako životní program dostatečně funkční a celistvý rámec podpírající jeho identitu, pokud není dospívající budoucí vrcholový sportovec. Sport nemůže být páteří hodnotového systému, snad jen $v$ době časné adolescence, potom může být pouze jeho součástí. S tématem hledání identity se přirozeně otevírá otázka smyslu a ta vyžaduje jiné odpovědi, než jednoduchou „tezi“ sportuj. ${ }^{23} \mathrm{~A}$ zde vyvstává výzva pro pedagogy, kteří pracují s mládeží v různých kontextech. V. E. Frankl (1997) rozlišoval zážitkové, tvůrčí a postojové hodnoty při naplňování smyslu. $V$ těchto aspektech je důležitá také osobnost pedagoga a jeho vlastní zvládnutí, at' už existenciálních či vývojových, konfliktů.

\section{DISKUSE}

Provedený výzkum doplňuje závěry dotazníkových šetření populace, která přináší především popisná data. Jeho zjištění by mohla být dále rozvinuta metodou zúčastněného pozorování. Autonomie vrstevnických skupin v adolescenci se týká také norem a hodnot regulujících postoje a chování ve vztahu k návykovým látkám. Můžeme se setkat s vrstevnickými skupinami, či dokonce tř́dními kolektivy, v obecné rovině také subkulturami, scénami, které projevují afinitu ve vztahu k nelegálním drogám. Je však potřeba dodat, že pokud jedinec přejde $z$ fáze experimentů a kontrolovaného užívání do fáze závislosti, z prostředí běžných vrstevnických skupin je vyloučen.

22 Zde se objevuje určitá ambivalence, Petr na jedné straně vyzdvihuje oporu, kterou mu komunita poskytuje, na druhé straně si uvědomuje, že je to svého druhu „svět pro sebe“.

23 Určitá koncepce spojená s péčí o tělo v dnešní kultuře je spíše než sokolský ideál narcistická idea těla, nebo idea „fitness" (srov. Bauman, 1995, 2002). Idea "fitness" nabízí určité pozitivní aspekty, které Ize ve výchově využít. 
Pokusme se o reflexi dat ve vztahu k soudobé sociokulturní situaci. Adolescent potřebuje kotvu také $\checkmark$ určité adekvátní ideologii, vycházíme-li z Eriksonovy koncepce. Problémem postmoderní situace může být, že zmizel společností sdílený výklad světa, který by s sebou nesl perspektivu budoucího. Subkultury se svými „ideologiemi“ v jistém smyslu suplují roli ideologií dřívější doby s hodnotovým a světonázorovým přesahem. Některé z těchto ideologií mají prodrogový charakter (srov. Kudrle, 2008).

Větší obecnou akceptaci hodnot hédonistických a hodnot, které Young označuje subterranean values, Ize vidět za větší akceptací dřive odmítaného jednání. Dochází na jedné straně $k$ větší toleranci plurality, vedle toho se ale také posunují a relativizují normy deviantního jednání. Existuje více referenčních rámců životních stylů a je tedy složitější určit, které jednání je nepřijatelné. ${ }^{24}$ To má pro adolescenci specifické důsledky. Užívání drog Ize vidět jako konzumní logiku dnešní společnosti dovedenou do krajnosti, stejně jako hledání alternativ k ní (srov. Slačálek, 2011). Sociální pedagog by neměl pomáhat jedincům pouze hledat pozitivní náplň volného času, ale funkční hodnotový a ideový rámec, nosný při hledání místa ve světě. Ten může být vyjádřený např. v postmaterialistické hodnotové orientaci (k sociologické konceptualizaci této kategorie Rabušic, 2000).

\section{LITERATURA}

Bauman, Z. (2002). Tekutá modernita. Praha: Mladá Fronta.

Bauman, Z. (1995). Úvahy o postmoderní době. Praha: Slon.

Becker, S. H. (1973). Outsiders, studies in the sociology of deviance. New York: The Free Press.

Beijaard, D. et al. (1999) Evaluation of story-line methodology in research on teachers practical knowledge. Studies in pedagogical evaluation, 25, 47-62.

Berger, P. L., Luckman T. (1999). Sociální konstrukce reality: pojednání o sociologii vědění. Brno: CDK.

Creswell, J. W. (2007). Qualitative inquiry and research design. Choosing among five approaches. London: Sage.

Csémy et al. (2009). Evropská školní studie o alkoholu a jiných drogách ESPAD - výsledky průzkumu $v$ ČR v roce 2007. Praha: Úřad vlády České republiky.

Erikson, E. H. (1994). Identity: youth and crisis. New York: W. W. Norton \& Company.

Erikson, E. H. (1999). Životní cyklus rozšírený a dokončený: doplněné vydání o devátém stupni vývoje od Joan M. Eriksonové. Praha: Lidové noviny.

Falář, J., Bolek, E. et al. (2003). Casri: Dynamika drogové scény a sociálního klimatu dětí a mládeže za období 1997-2000. Brno: Ústav psychologického poradenství a diagnostiky.

Falář, J., Bolek, E. et al. (2004). Casri: Dynamika drogové scény a sociálního klimatu mládeže 19972001. Brno: Ústav psychologického poradenství a diagnostiky.

Frankl, V., E. (1997). Vůle ke smyslu. Brno: Cesta.

Hendl, J. (2005). Kvalitativní výzkum: Základní metody a aplikace. Praha: Portál.

Kudrle, S. (2008). Bio-psycho-sociálně-spirituální model závislosti jako východisko k primární, sekundární a terciární prevenci a kvalifikované pomoci. In K. KALINA (Ed.), Základy klinické adiktologie (s. 17-24). Praha: Grada.

Macek, P. (2003). Adolescence. Praha: Portál.

24 To však neznamená, že by neexistovaly deviantní životní styly v Beckerově smyslu. 
Marcia, J. E. (1966). Development and validation of ego - identity status. Journal of Personality and Social Psychology, 3(5), 551-558.

Mareš, P. (1999). Sociologie nerovnosti a chudoby. Praha: Slon.

Miles, M. B., Huberman, A. M. (1994). Qualitative data analysis. An expanded sourcebook. London: Sage.

Nešpor, K. (2007). Návykové chování a závislosti. Praha: Portál.

Pelikán, J. (2002). Pomáhat být: otevřené otázky teorie provázející výchovy. Praha: Karolinum.

Rabušic, L. (2000). Je česká společnost „postmaterialistická“? Sociologický časopis, 36(1), 3-22.

Rogers, C., R. (1998). Způsob bytí: klíčová témata humanistické psychologie z pohledu jejího zakladatele. Praha: Portál.

Slačálek, O. (2011). České freetekno - pohyblivé prostory autonomie? In M. KOLÁŘOVÁ (Ed.), Revolta stylem: hudební subkultury mládeže v české republice (s. 83-122). Praha: Slon.

Švaříček, R., Šed'ová, K. et al. (2007). Kvalitativní výzkum v pedagogických vědách. Praha: Portál.

Young, J. (1971). The Subterranean world of play. In K. GELDER, S. THORNTON (Eds.), The Subcultures Reader. 1997. 71-80. London: Routledge.

Zaostřeno na drogy. (2012). 10 (1).

\section{PŘ́LOHY}

Tabulka 3

Drogy a třídní kolektiv

\begin{tabular}{|c|c|c|}
\hline Jméno & $\begin{array}{l}\text { Vztah tř́idního kolektivu } \\
\text { k drogovým experimentům }\end{array}$ & Sociální důsledky v třídním kolektivu \\
\hline Adéla & $\begin{array}{l}\text { SŠ - Odmítavý, vyloučena } \\
\text { z kolektivu }\end{array}$ & Exkluze na SŠ \\
\hline Bohouš & $\begin{array}{l}\text { Třídní kolektiv bez vztahu } \\
\text { k drogové kariéře, rozšířenost } \\
\text { tam neotevřené téma, dá se } \\
\text { předpokládat, že minimální }\end{array}$ & bez důsledků \\
\hline Cyril & $\begin{array}{l}\text { Ano, skoro celá třída na SOU } \\
\text { konzumovala drogy }\end{array}$ & Chápe spíše jako kladné \\
\hline David & $\begin{array}{l}\text { Ano, užší skupina tří kamarádů na } \\
\text { učilišti }\end{array}$ & Subjektivně vnímal bez závažnějších důsledků \\
\hline Evžen & $\begin{array}{l}\text { Ano, subjektivně odtud odvozuje } \\
\text { svůj statut hvězdy }\end{array}$ & Subjektivně statut hvězdy \\
\hline František & $\begin{array}{l}\text { Ano, iniciace marihuany přes } \\
\text { kamaráda ze třídy ZŠ }\end{array}$ & Subj. nemělo negativní důsledky \\
\hline Gustav & Minimální & $\begin{array}{l}\text { negativní zpětná vazba od vrstevníků v době } \\
\text { závislosti }\end{array}$ \\
\hline Hana & $\mathrm{Ne}$ & Nebrala v době školní docházky \\
\hline Iva & $\mathrm{Ne}$ & Exkluze, outsider - na ZŠ i SOU \\
\hline Jaroslav & $\begin{array}{l}\text { Ano, 1. drogu sehnala spolužačka } \\
\text { ze ZŠ }\end{array}$ & $\begin{array}{l}\text { Dva referenční rámce - konzumenti a } \\
\text { nekonzumenti }\end{array}$ \\
\hline Karel & Ano po 1. od spolužáka ze SOU & Konzumace drog neměla negativní dopad \\
\hline
\end{tabular}




\begin{tabular}{|c|c|c|}
\hline Leoš & $\begin{array}{l}\text { Ano, experimentoval s vrstevníky } \\
\text { z místa bydliště i gymnaziální } \\
\text { třídy }\end{array}$ & Subj. Pocit exkluzivity, později exkluze \\
\hline Marta & $\mathrm{Ne}$ & Exkluze, cizost na SŠ \\
\hline Nela & $\mathrm{Ne}$, vztah $\mathrm{k}$ alkoholu & Na SŠ tmel alkohol, marihuana okrajově \\
\hline Olga & $\begin{array}{l}\text { Ano, pro iniciaci, na SŠ parta } \\
\text { „fetáků“ }\end{array}$ & $\begin{array}{l}\text { Nebránilo v začlenění - subj., nicméně spolužačky } \\
\text { udaly, že bere drogy }\end{array}$ \\
\hline Petr & Není výrazný, sám prodával & Subj. dodávalo prestiž \\
\hline Roman & Ano, na SOU & $\begin{array}{l}\text { Na SOU nepůsobilo exkluzi, na ZŠ nálepka } \\
\text { narkomana pro styky s pouličními punkery, }\end{array}$ \\
\hline Stanislav & Okrajový, spolužáci na SOU & Integrativní prvek s některými spolužáky na SOU \\
\hline \multicolumn{3}{|c|}{ Pozn. zdroj: autor. } \\
\hline \multicolumn{3}{|c|}{ Tabulka 4} \\
\hline \multicolumn{3}{|c|}{ Motivy braní drog } \\
\hline Jméno & Fascinace drogami od dětství & Další naznačené motivy braní drog \\
\hline Adéla & Ano, silný drogový romantismus & touha nežít šedivý život průměru, subj. Únik \\
\hline Bohouš & Není patrno & $\begin{array}{l}\text { Silný motiv hledání, subj. proklamována touha } \\
\text { někam patřit a odbourávání stydlivosti }\end{array}$ \\
\hline Cyril & $\begin{array}{l}\text { Fascinace na sociálním základě } \\
\text { (imponovala mu marihuana a lidé } \\
\text { s ní spojení) }\end{array}$ & é Vliv vrstevnické skupiny \\
\hline David & $\mathrm{Ne}$ & Být odlišný a „důležitý“ - subj. \\
\hline Evžen & Ano & $\begin{array}{l}\text { Subjektivně dodávaný status, fascinace } \\
\text { drogami, odlišnost }\end{array}$ \\
\hline František & $\mathrm{Ne}$ & Motiv zvědavosti, zkoušení \\
\hline Gustav & $\mathrm{Ne}$ & Touha po odlišnosti \\
\hline Hana & $\begin{array}{l}\text { Ano, zajímaly ji filmy o drogách, } \\
\text { děsilo jí to a zároveň táhlo to zkusit }\end{array}$ & , Řešení vztahových problémů \\
\hline Iva & $\begin{array}{l}\text { Ano, již dřive chtěla zkusit, hodně si } \\
\text { o tom zjištovala }\end{array}$ & i ? \\
\hline Jaroslav & $\mathrm{Ne}$ & Subj. touha experimentovat \\
\hline Karel & Není jako téma př́tomno & Silné oslovení drogovou intoxikací \\
\hline Leoš & Není jako téma prítomno & $\begin{array}{l}\text { Drogy dodávaly pocit exkluzivity, subj. } \\
\text { Vysvětlení útěk před zodpovědností, nízké } \\
\text { sebevědomí }\end{array}$ \\
\hline Marta & Ano, drogový romantismus & ? drogy dodávaly pocit identity \\
\hline Nela & $\begin{array}{l}\text { Ano, objevoval se určitý zájem o } \\
\text { drogy }\end{array}$ & Subj. touha být výjimečná skrze drogy \\
\hline Olga & Ano, drogový romantismus & fascinace „syrovým“ světem drog, vliv stylu \\
\hline Petr & $\mathrm{Ne}$ & ? \\
\hline Roman & Není jako téma prítomno & $\begin{array}{l}\text { drogy součást životního stylu vrstevnické } \\
\text { skupiny }\end{array}$ \\
\hline Stanislav & $\mathrm{Ne}$ & vliv starších vrstevníků \\
\hline
\end{tabular}

Pozn. zdroj: autor.

\section{Autor}

Mgr. Martin Stanoev, Centrum empirických výzkumu, Fakulta veřejných politik, Slezská univerzita v Opavě, Hradecká 17, e-mail: martin.stanoev@fvp.slu.cz 


\title{
The path to addiction and back
}

\begin{abstract}
The article presents selected findings of research of drug careers focused on the social consequences, which is currently being completed in the author's dissertation. The aim of the thesis research was to transcribe changes in the social environment of individual drug careers of those individuals whose process of addiction begins in adolescence and does not come from a socially marginalized environment. The particular aim was to extract relevant conclusions for the helping professions. The sample consists of eighteen informants, the sample design goal was to include cases of a comparable nature. The research uses a case study design and analytical procedures and the main and key data collection method is an in-depth interviews with a script. Interviews had elements of a narrative interview and retrospectively identified drug career. Selected findings focus on the climate associated with the use of non-alcohol drugs in a school class team, recognising the identification with the anti-hero of the addicted individual as a surprising motive for drug use, and analysing the moment of balance as an opportunity for intervention of helping professions. The author tries to put the findings into a broader sociocultural context and reflects on the contemporary context of identity formation in adolescence and the question of normality/deviance in relation to illicit drug use.
\end{abstract}

Keywords: adolescence, case study, deviance, drug addiction, peer groups 